\title{
NSE and S100 after Hypoxia in the Newborn Pig
}

\author{
ZSUZSOKA KECSKES, KIMBLE R. DUNSTER, AND PAUL B. COLDITZ \\ Royal Children's Hospital [Z.K.], Herston Road, Herston, Queensland, 4029, Australia, Perinatal \\ Research Centre [Z.K., K.R.D., P.B.C.], The University of Queensland, Royal Women's Hospital, \\ Butterfield Street, Herston, Queensland, 4029, Australia
}

\begin{abstract}
Perinatal asphyxia is an important cause of neonatal morbidity and mortality. There is the potential to halt cerebral damage if neural rescue strategies are applied within a short period of time after an insult. It is therefore important to be able to accurately identify neonates who may benefit from neural rescue therapies. Recent studies in asphyxiated neonates have correlated S100B and NSE with outcome; however, interpretation of these studies were difficult, as the timing of the measurements were not consistent. We measured NSE and S100 in 1-d-old piglets after a mild or severe hypoxic insult. Measurements were performed at 6-72 h after the insult and correlated with histologic outcome. There were no differences of the NSE or S100 concentrations between controls and the mild hypoxia group. After $24 \mathrm{~h}$, there was a significant difference of NSE between the control/mild insult group and severe insult group. After $48 \mathrm{~h}$, the S100
\end{abstract}

ABSTRACT

concentrations were significantly different between the control/ mild insult group and the severe insult group. Both proteins showed good correlation at these time points with outcome as measured by histology score at $72 \mathrm{~h}$. In conclusion, NSE and S100B measured in the serum of piglets after hypoxia increased significantly and correlated with outcome. This increase occurs too late to be used within the first $24 \mathrm{~h}$ but might be helpful for the clinician in determining the timing of an insult. (Pediatr Res 58: 953-957, 2005)

\section{Abbreviations}

CFM, cerebral function monitor

CSF, cerebrospinal fluid

IRMA, immunoradiometric assay

NSE, neuron-specific enolase
Perinatal asphyxia occurs in 1 in 500 deliveries and is an important cause of neonatal morbidity and mortality. There is the potential of neural rescue therapies to halt cerebral damage when applied within a "window of opportunity" of limited duration. It is therefore especially important to be able to accurately identify those neonates who may benefit from such interventions (1). The early and accurate prediction of the severity of brain damage remains difficult.

Several brain-specific proteins have been measured in CSF and serum and correlated with outcome after hypoxic/ischemic reperfusion injury (1-4). S100 is an astroglial specific protein with calcium binding capacity. It is a homo- or heterodimer consisting of two subunits, alpha and beta. S100 $\beta \beta$ is present in high concentrations in glial and Schwann cells, S100 $\alpha \alpha$ in glial cells, and $\mathrm{S} 100 \alpha \beta$ in striated muscle, heart, and kidney (5). NSE is an isoenzyme of the glycolytic enzyme enolase and is present in high concentrations in neuronal cell bodies, axons, and in cells of neuroendocrine origin (6). After neuronal injury,

Received August 25, 2004; accepted April 11, 2005.

Correspondence: Zsuzsoka Kecskes, M.D., Department of Neonatology, The Canberra Hospital, Yamba Drive, Garran, ACT, 2605, Australia; e-mail: zsuzsoka.kecskes@ act.gov.au

Supported by the Royal Children's Hospital Foundation and the Royal Women's Hospital Foundation.

DOI: 10.1203/01.PDR.0000182591.46087.7D
S100B (S100 $\beta \beta)$ and NSE pass into the CSF and across the blood-brain-barrier $(6,7)$. Recent studies in asphyxiated neonates have correlated S100B and NSE with outcome $(3,4,8,9)$. The results correlated with outcome but measurements had been taken at differing and unknown times after insult and from different bodily fluids (serum or CSF). As the probable beginning and duration of the insult in neonates is often uncertain, correlations with outcome are difficult to interpret as the timeline of the increase of NSE or S100 after an insult is not known.

The aims of the current study were to measure NSE and S100B at various times in serum of piglets subjected to hypoxia and to determine whether NSE and S100B are early predictors of outcome.

\section{METHODS}

Animal preparation. The study was approved by the University of Queensland Animal Experimentation Ethics Committee. Experiments were carried out in accordance with the Australian National Health and Medical Research Council Guidelines. Adequate measures were taken to minimize pain or discomfort during the experimental procedures. Seventeen term piglets (Large White $\times$ Landrace) were studied on $\mathrm{d} 1$ after birth, after a period of suckling.

Anesthesia was induced with 1-2\% halothane (Rhône Mérieux, Melbourne, Australia) in air. A 24-gauge catheter was inserted into an ear vein and an induction dose of propofol $(5 \mathrm{mg} / \mathrm{kg})$ administered. A mixed infusion of propofol $(10 \mathrm{mg} / \mathrm{kg} / \mathrm{h})$ and alfentanil $(55 \mu \mathrm{g} / \mathrm{kg} / \mathrm{h})$ was used to maintain anesthesia until the piglet was intubated with a size- 3 cuffed endotracheal tube. 
The piglet was then ventilated with a neonatal ventilator (Bearcub, Bourns, CA) to maintain oxygen saturation above $95 \%$ and arterial $\mathrm{PCO}_{2}$ at $30-50 \mathrm{~mm}$ $\mathrm{Hg}$. The infusion rate of the intravenous anesthesia was then increased to deliver propofol at $20 \mathrm{mg} / \mathrm{kg} / \mathrm{h}$ for $15 \mathrm{~min}, 15 \mathrm{mg} / \mathrm{kg} / \mathrm{h}$ for $15 \mathrm{~min}$, then 10 $\mathrm{mg} / \mathrm{kg} / \mathrm{h}$ for the remainder of the anesthetic. A 24-gauge cannula was inserted into a mammary vein and $10 \%$ glucose infused at $3 \mathrm{~mL} / \mathrm{kg} / \mathrm{h}$. The umbilical artery was cannulated using a $3.5 \mathrm{~F}$ neonatal umbilical catheter (Argyle, Sherwood Medical Co., St. Louis, MO). Temperature was measured rectally and maintained at $39.0 \pm 0.5^{\circ} \mathrm{C}$, which is the normal temperature for piglets. EEG was monitored using a cerebral function monitor (CFM; Lectromed Devices Ltd., Letchworth, Hertfordshire, UK).

After a standardized stabilisation period (120 min after induction of anesthesia), the oxygen intake was decreased to $3-7 \%$ as required to suppress the EEG to $<5 \mu \mathrm{V}$. A mild insult was defined as 20 min of suppressed EEG and a severe insult was defined as 40 min of suppressed EEG. The piglets subjected to a severe insult also had a minimum of $10 \mathrm{~min}$ of hypotension (mean arterial blood pressure $<70 \%$ of prehypoxia). The mean arterial blood pressure was controlled by manipulating the inspired oxygen within the range of 3-7\%. A brief increase in $\mathrm{FiO}_{2}$ prevented hypotension, a decrease resulted in hypotension. Hypotension was not caused by blood withdrawal but was a direct result of the hypoxic insult.

Piglets were then reoxygenated with $100 \%$ oxygen, and the metabolic acidosis half corrected with $8.4 \%$ sodium bicarbonate given intravenously. The anesthesia was discontinued, the ventilation weaned according to blood gas analysis, and the piglet extubated. The arterial and venous lines removed because the piglets were housed together in a cage and more active animals would bite through the indwelling their catheters as well as those of the other piglets. Piglets were then nursed in a warmed cage, fed via an orogastric tube every 2-3 h with piglet milk formula (Survive, Pig Milk Replacer, Aus Vac, Bendigo, Australia). A carer observed the piglets for $72 \mathrm{~h}$. The piglets were assessed every $8 \mathrm{~h}$ for $24 \mathrm{~h}$ and at 48 and $72 \mathrm{~h}$ using a neurology score as described by Thoresen et al. (10). The scoring system consists of nine neurologic items that are scored from 0 (definitely pathologic) to 2 (normal) and added up to a maximum score of 18 for a normal piglet. Piglets were also monitored at these time points using a CFM. Seizures were defined as rhythmic pathologic movement of the limbs or repetitive spike wave activity on the CFM. Clinical and electrographic seizures were treated with diazepam (DBL, Mulgrave, Australia) and phenobarbitone (DBL) if they occurred. Control animals were subjected to the same procedures and length of anesthesia as the hypoxic piglets except for the hypoxic insult

Blood for measurement of NSE and S100B was taken before to the insult and at $6,12,24,48$, and $72 \mathrm{~h}$ after the insult. The piglets were anesthetized with halothane for the purpose of blood sampling and CFM measurement. The blood was allowed to clot for $30 \mathrm{~min}$ at room temperature, centrifuged at 3000 $\mathrm{rpm}$ for $10 \mathrm{~min}$, and the serum frozen at $-20^{\circ} \mathrm{C}$ until the assay was performed. Commercially available radioimmunoassays for S100B (Sangtec S100 IRMA, Sangtec Medical, Bromma, Sweden) and NSE (Prolifigen NSE IRMA, Sangtec Medical) were used. Each measurement was performed in duplicate according to the manufacturer's recommendations, and the averages are reported. The sensitivities of the assays are reported by the manufacturers to be 0.1 and 0.5 $\mu \mathrm{g} / \mathrm{L}$, respectively.

In this study, histopathological changes visible $72 \mathrm{~h}$ after the insult were used as the outcome measurement. At $72 \mathrm{~h}$ posthypoxia, the piglets were killed and the brains perfused via both carotid arteries with warmed heparinized saline and then $4 \%$ paraformaldehyde. After this, the brains were removed, cut at 3-4 $\mathrm{mm}$ intervals into coronal sections, embedded in paraffin, and then cut for histologic examination into $8-\mu \mathrm{m}$ sections. The first, 50 th and 100 th section from either hemisphere from the cortex, hippocampus, basal ganglia, thalamus, cerebellum, and medulla were stained with hematoxylin/eosin. The extent of damage for each brain region was graded as previously described (11) at 72-h post insult. Cell death was graded from 0 to 9 in each brain region. Each grade reflected the percentage of damage in three ascending categories (Table 1). The categories were neuronal necrosis, laminar/focal necrosis, and confluent infarct. The highest possible score for the five brain regions was 45, representing maximal damage (confluent necrosis in all areas).

Statistics. All values are presented as mean and SD as they were normally distributed unless otherwise indicated. Comparisons between groups were performed using one-way ANOVA with Bonferroni correction for repeated testing or Kruskal-Wallis test if not normally distributed. Pearson's correlation coefficient was used to test for correlation between variables. Probability values $<0.05$ were considered to be significant.

\section{RESULTS}

Five control animals, five subjected to a mild insult, and seven subjected to a severe insult were studied. There were no
Table 1. Grading scale for histopathological changes 72 hours after a hypoxic insult in neonatal piglets

\begin{tabular}{ccc}
\hline Changes in morphology & $\%$ of area affected & Grade \\
\hline No damage & 0 & 0 \\
Neuronal necrosis & $<20$ & 1 \\
& $20-50$ & 2 \\
& $>50$ & 3 \\
Laminar necrosis & $<20$ & 4 \\
& $20-50$ & 5 \\
Confluent infarct & $>50$ & 6 \\
& $<20$ & 7 \\
& $20-50$ & 8 \\
\hline
\end{tabular}

differences in the birth weights or postnatal ages of the groups. Table 2 outlines the physiologic parameters of all piglets before and after the insult, i.e. at the beginning of resuscitation. One piglet died from presumed septicemia $60 \mathrm{~h}$ after the insult, four in the severe insult group had clinical seizures, and no piglet had electrographical seizures that were not detected clinically. All of the control animals and the animals exposed to a mild insult recovered quickly and demonstrated normal behavior $24 \mathrm{~h}$ post hypoxia. Five of the animals that underwent a severe insult were neurologically abnormal, i.e. were not able to walk or feed within the first $12 \mathrm{~h}$ (Table 3).

Histology. All control animals and the animals exposed to a mild insult had normal histology $72 \mathrm{~h}$ after the insult. In contrast, none of the animals exposed to a severe insult had normal histology at that time point. All demonstrated moderate-to-severe changes such as necrosis and apoptosis. The cortex showed the most severe changes with confluent infarction. The hippocampus was affected consistently by neuronal necrosis and the basal ganglia and thalamus showed focal areas of neuronal necrosis. The combined histology score of the in the severe insult group was significantly higher than that of the control or mild insult group (Fig. 1) The mean (SD) histology score for the control group was $0(0)$, for the mild insult group

Table 2. Physiologic parameters of piglets before and at the end of insult

\begin{tabular}{lccc}
\hline & $\begin{array}{c}\text { Controls } \\
(\mathrm{n}=5)\end{array}$ & $\begin{array}{c}\text { Mild insult } \\
(\mathrm{n}=5)\end{array}$ & $\begin{array}{c}\text { Severe insult } \\
(\mathrm{n}=7)\end{array}$ \\
\hline age (hours) & $16.6(10.9)$ & $10(4.0)$ & $12.8(7.6)$ \\
weight $(\mathrm{kg})$ & $1.2(0.26)$ & $1.6(0.2)$ & $1.6(0.3)$ \\
$\mathrm{pCO}_{2}$ before insult $(\mathrm{mmHg})$ & $35.7(0.8)$ & $36.8(8.4)$ & $39.7(8.2)$ \\
$\mathrm{BP}$ before insult $(\mathrm{mmHg})$ & $59.3(1.7)$ & $57.6(7.5)$ & $58.1(4.1)$ \\
$\mathrm{BP}$ at end of insult $(\mathrm{mmHg})$ & $62.9(2.3)$ & $56.9(8.5)$ & $46.3(5.9)^{*}, \S$ \\
min BP at end of insult & $55.6(3.2)$ & $35.5(4.2)$ & $29.2(4.4)^{*}, \S$ \\
$\mathrm{HR}$ before insult & $180.8(43.8)$ & $170.15(43.5)$ & $170.6(22.2)$ \\
$\mathrm{HR}$ at end of insult & $182.7(32.7)$ & $202.5(25.6)$ & $183.3(17.9)$ \\
$\mathrm{min}^{\mathrm{H} R}$ at end of insult & $138.2(36.9)$ & $107.7(19.5)$ & $125.8(21.9)$ \\
$\mathrm{SaO}$ at end of insult & $86.6(14.9)$ & $42.2(10.7)^{*}$ & $37.0(8.7)^{*}, \S$ \\
$\mathrm{pO}_{2}$ at end of insult & $121.9(21.9)$ & $42.13(44.5)^{*}$ & $17.56(3.9)^{*}, \S$ \\
$\mathrm{pH}^{2}$ at end of insult & $7.41(0.2)$ & $7.07(0.4)^{*}$ & $6.9(0.16)^{*}$ \\
$\mathrm{BE}$ at end of insult $^{2}$ & $5.6(7.5)$ & $-12.8(4.9)^{*}$ & $-19.3(3.5)^{*}, \S$ \\
\hline
\end{tabular}

numbers are mean $(\mathrm{SD})$

BP: blood pressure, HR: heart rate in beats per minute, $\mathrm{SaO}_{2}$ : oxygen saturation, BE: base excess

$*: p<0.05$ vs control group

$\S: p<0.05$ vs mild insult group 
Table 3. Results of the neurology and histology scores in piglets up to 72 hours after a hypoxic insult

\begin{tabular}{lccc}
\hline & $\begin{array}{c}\text { Controls } \\
(\mathrm{n}=5)\end{array}$ & $\begin{array}{c}\text { Mild insult } \\
(\mathrm{n}=5)\end{array}$ & $\begin{array}{c}\text { Severe insult } \\
(\mathrm{n}=7)\end{array}$ \\
\hline neuroscore at 12 hours & $16.0(4)$ & $13.5(1.3)$ & $9.67(3.2)$ \\
neuroscore at 24 hours & $18.0(1.7)$ & $17.3(1.5)$ & $12.33(5.3)^{*}$ \\
neuroscore at 72 hours & $18.0(2.2)$ & $17.2(1.5)$ & $14.5(5.2)$ \\
histology score at 72 hours & $0(0)$ & $0.5(1)$ & $13.63(6.8)^{*}, \S$ \\
\hline
\end{tabular}

numbers are mean (SD)

$*: p<0.05$ vs control group

$\S: p<0.05$ vs mild insult group

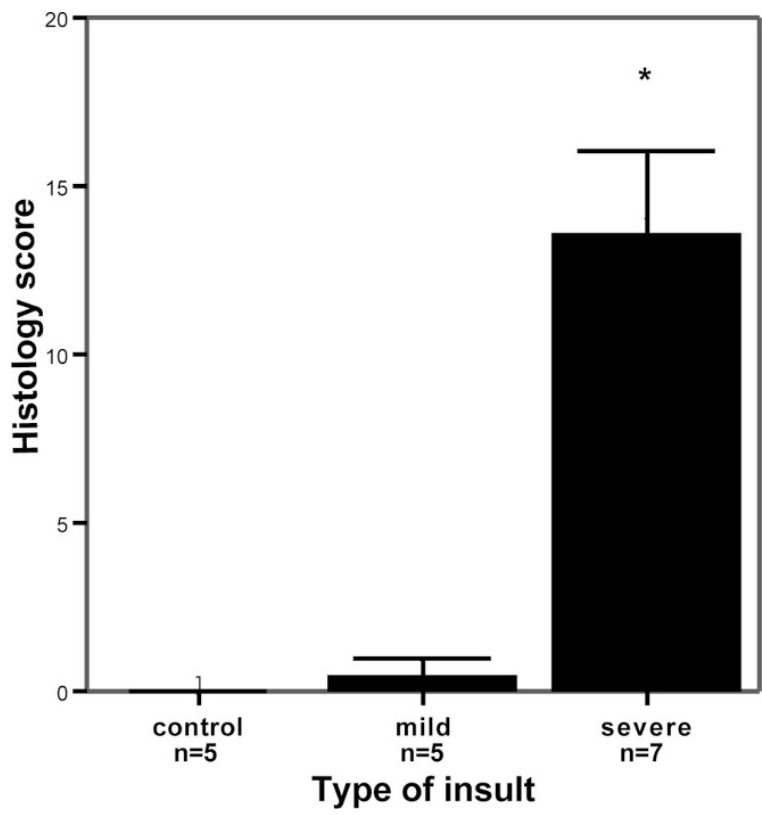

Figure 1. Histology score $72 \mathrm{~h}$ after hypoxia in newborn piglets. Numbers are given as median \pm SEM. ${ }^{*} p<0.01$ compared with control and mild hypoxia.

0.5 (1), and for the severe insult group 13.6 (6.8), $p<0.05$ (control versus severe and mild versus severe).

NSE. Concentrations before the insult were not different among the three groups. There were no statistically significant differences in the concentrations of the control animals when compared with the mild hypoxia group at any time point (Fig. 2). After $24 \mathrm{~h}$, however, there was a significant difference between the concentrations of the control/mild insult group and severe insult group. This difference persisted up to $72 \mathrm{~h}$.

The correlation of the histology score with NSE concentrations at the different time points supported above results. At $24 \mathrm{~h}$ the correlation coefficient $(r)$ was 0.89 , the coefficient of determination $\left(r^{2}\right)$ was 0.8 ; at $48 \mathrm{~h}, r=0.95$ and $r^{2}=0.9$; and at $72 \mathrm{~h}, r=0.97$ and $r^{2}=0.94$ (Fig. 3).

In the group of piglets subjected to a severe insult there were no differences in the NSE concentrations between the piglets with seizures and those that did not have seizures. In that group there were also no differences in the NSE concentrations when comparing the piglets with higher neurology scores to those with lower, very abnormal neurology scores.

S100B. Concentrations before the insult were not different among the three groups. There were no statistically significant differences in the concentrations of the control animals when

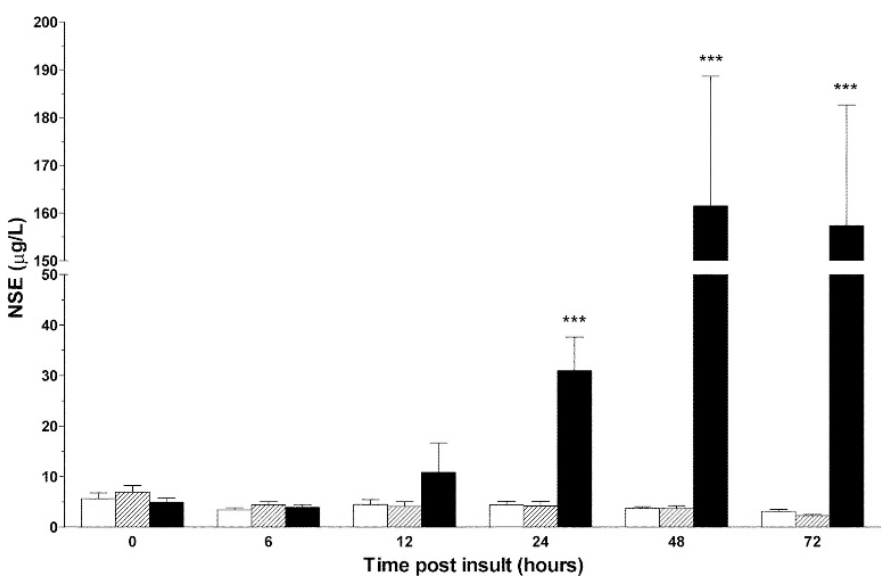

Figure 2. Serum concentrations of $\mathrm{S} 100$ measured in newborn piglets after hypoxia. Numbers are given as median \pm SEM. $* * p<0.001$ compared with control and mild hypoxia. Control animals (white bars, $n=5$ ); animals subjected to mild hypoxia (shaded bars, $n=5$ ); animals subjected to severe hypoxia (black bars, $n=7$ ).

compared with the mild hypoxia group at any time point (Fig. 4). From $48 \mathrm{~h}$ after insult, there was a significant difference between the concentrations of the control/mild insult group when compared with severe insult group. This difference was still present at $72 \mathrm{~h}$.

Correlating the histology score with 100B concentrations gave the following results: At $48 \mathrm{~h}$ the correlation coefficient $(r)$ was 0.9 , the coefficient of determination $\left(r^{2}\right)$ was 0.8 ; and at $72 \mathrm{~h}, r=0.81$ and $r^{2}=0.64$ (Fig. 5).

Comparing the piglets subjected to a severe insult with seizures to those subjected to a severe insult without seizures, there were no differences the S100B concentrations. There were also no differences in the S100B concentrations when comparing the piglets with higher neurology scores to those with lower, very abnormal neurology scores in that severe insult group.

\section{DISCUSSION}

This study outlines the time course of NSE and S100B in serum after a hypoxic period in a newborn animal model. The piglet was chosen, as it is similar to the term human infant in size, development, and cerebral maturation (12). The amino acid sequences of the porcine NSE and S100B are not known, but the protein is well preserved between species (13-15). The baseline values of NSE and S100 $\beta$ in the piglets were comparable to the values found in term neonates in cord blood (3). This suggests sufficient similarity between the human and the porcine proteins for the RIA to measure porcine proteins accurately.

Elevations of NSE and S100B have been found in various forms of acute brain damage in adult patients. Measured in CSF, they are sensitive markers for brain damage after head trauma (2), ischemic stroke, and cerebral hypoxia $(7,16)$. When measured in serum, both show good correlation with outcome after ischemic stroke and cardiac arrest (17-20).

NSE measured in amniotic fluid of women in preterm labor has been found to correlate with intraventricular hemorrhage or 

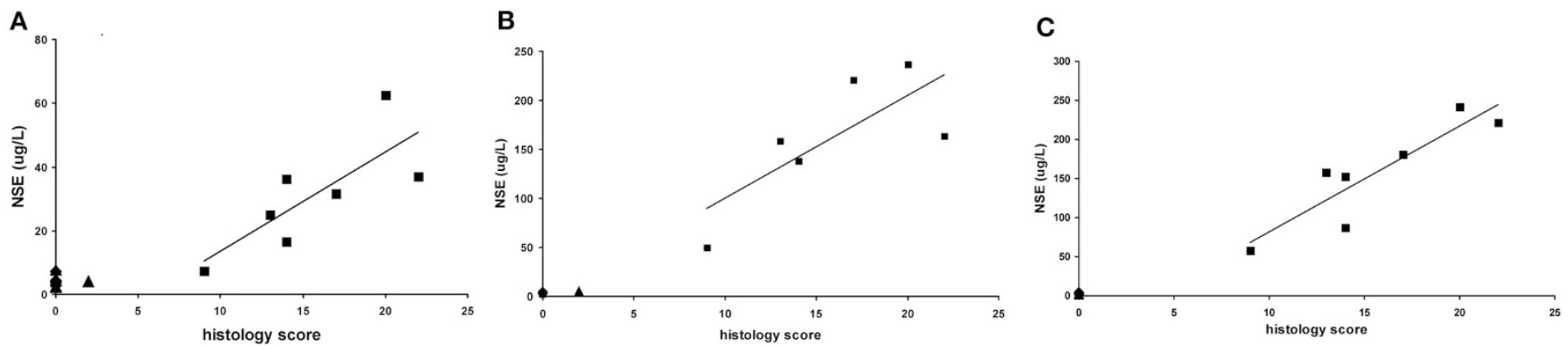

Figure 3. Correlation between serum concentrations of NSE and histology score in newborn piglets: $(A) 24 \mathrm{~h}$ after a hypoxic insult, $\mathrm{R}^{2}=0.8,(B) 48 \mathrm{~h}$ after a hypoxic insult, $\mathrm{R}^{2}=0.9$, and $(C) 72 \mathrm{~h}$ after a hypoxic insult, $\mathrm{R}^{2}=0.94$. Control animals (diamonds, $n=5$ ); animals subjected to mild hypoxia (triangles, $n=5$ ); animals subjected to severe hypoxia (squares, $n=7$ ).

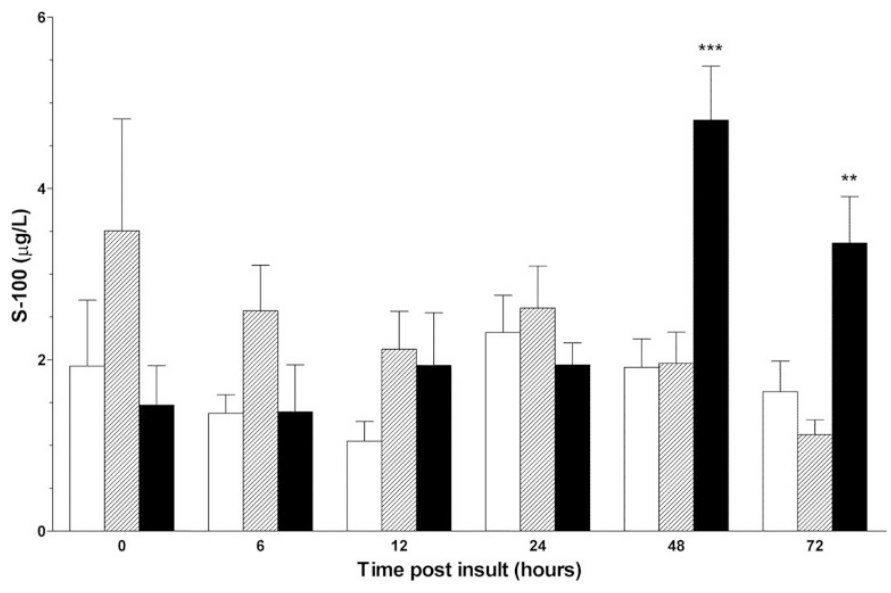

Figure 4. Serum concentrations of S100B measured in newborn piglets after hypoxia. Numbers are given as median \pm SEM. $* p<0.01$ compared with control and mild hypoxia; **p $<0.001$ compared with controls and mild hypoxia. Control animals (white bars, $n=5$ ); animals subjected to mild hypoxia (shaded bars, $n=5$ ); animals subjected to severe hypoxia (black bars, $n=7)$.
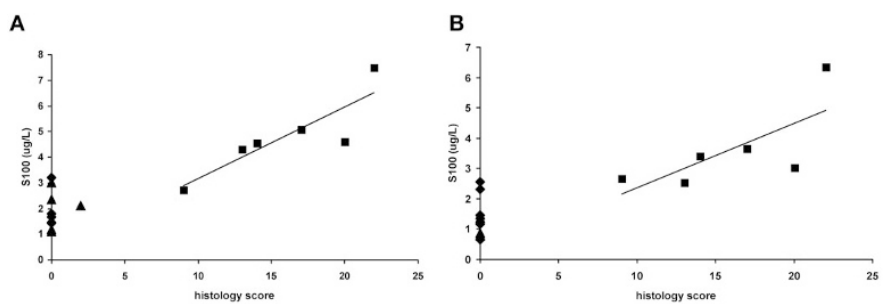

Figure 5. Correlation between serum concentrations of S100B and histology score in newborn piglets: $(A) 48 \mathrm{~h}$ after a hypoxic insult, $\mathrm{R}^{2}=0.8$ and $(B) 72 \mathrm{~h}$ after a hypoxic insult, $\mathrm{R}^{2}=0.64$. Control animals (diamonds, $n=5$ ); animals subjected to mild hypoxia (triangles, $n=5$ ); animals subjected to severe hypoxia (squares, $n=7$ ).

periventricular leukomalacia (21). S100 measured in preterm infants, may be an indicator of white matter lesions (22). In the pediatric population, S100 has been measured after cardiac surgery and correlated with cerebral injury (23).

Concentrations of S100B and NSE have been measured in the CSF of neonates following perinatal asphyxia in three studies. Garcia-Alix et al. measured NSE in CSF from 69 asphyxiated term newborn infants 12 and $72 \mathrm{~h}$ after birth (8). NSE at both time points correlated well with degree of encephalopathy and neurodevelopmental outcome at $1 \mathrm{y}$ of age. Thornberg et al. (1) used CFM and measured NSE in CSF of
22 asphyxiated term infants between 2 and $96 \mathrm{~h}$ after birth. In 15 of these infants, NSE was also measured in serum between 2 and $64 \mathrm{~h}$ after birth, and in both CSF and serum simultaneously in 10 infants. NSE in CSF correlated well with degree of encephalopathy and CFM pattern. Blennow et al. (4) recently measured NSE and S100B in CSF of 22 asphyxiated infants between 6 and $89 \mathrm{~h}$ after birth. Both proteins correlated with degree of encephalopathy as well as outcome at $4 \mathrm{y}$ of age.

However, collecting CSF samples by lumbar puncture in a sick neonate may be technically difficult and may lead to hemodynamic compromise. Urine or blood sampling is associated with less risk to the infant and allows more frequent testing to monitor the course of the injury. Gazzolo et al. (24) measured S100B in the urine of 44 asphyxiated infants at 4-72 $\mathrm{h}$ of birth and compared with healthy controls. S100B concentrations in moderately/severely asphyxiated neonates were significantly higher than in controls and mildly asphyxiated infants. Verdu et al. (9) determined NSE in serum of 25 asphyxiated infants between 24 and $72 \mathrm{~h}$ after birth. Median follow-up time of these infants was $3.5 \mathrm{y}$. NSE levels were significantly higher in infants with encephalopathy who developed neurologic sequelae when compared with infants with normal outcome. Nagdyman et al. (3) assessed NSE and S100B in serum of 29 asphyxiated infants in cord blood and 2, 6,12 , and $24 \mathrm{~h}$ after birth. Serum S100B was found to be significantly higher in neonates with severe or moderate encephalopathy at 2 and $6 \mathrm{~h}$ after birth when compared with infants with no or mild encephalopathy. Serum NSE was significantly higher in infants with moderate or severe encephalopathy at 12 and $24 \mathrm{~h}$ when compared with infants with no or mild encephalopathy. However, the NSE and S100B levels did not correlate with long-term neurologic outcome. In the present study, the outcome measure used was histology. This is an objective tool to assess cerebral damage. The NSE and S100B levels showed good correlation with histology, indicating that the significant increase in the piglets subjected to a severe hypoxic period is caused by severe neuronal damage with subsequent release of these proteins. The levels measured were comparable to those reported by other authors in asphyxiated neonates $(3,8,9)$ but were lower than those reported in adult patients following stroke (17) or cardiac arrest $(18,19)$. There are several possible reasons for this: Firstly, the immature, newborn brain contains less glial and axonal mass and myeli- 
nation (25), which may account for the observed lower serum concentrations of NSE and S100. Secondly, in ischemic adult stroke, damage generally develops quickly and significant cell death occurs within 12-24 h with slower cell death, between 2 and $3 \mathrm{~d}$ occurring to a lesser extent (26). In global ischemia of the immature brain, it may be that cell death occurs more slowly, with apoptosis being a major and delayed component, resulting in an attenuated release of proteins from damaged cells into the CSF and serum $(27,28)$.

Neonates included in previous studies fulfilled varying definitions of perinatal asphyxia and the timing and nature of the insult was unknown. Antenatal and intrapartum monitoring techniques such as cardiotocography are unreliable in assessing the timing of an insult. Biochemical markers may be more accurate in defining the onset of a hypoxic insult. However, to be able to be used as predictors of outcome after perinatal asphyxia, the relationship between insult time and time to peak, as well as relationship between the peak level and outcome has to be known. That means multiple blood samples need to be taken to identify the peak level and determine the timing of the insult. Only one study reliably evaluated the time course of NSE in serum. In the study by Schorkhueber et al. (18), NSE was measured in 56 adult patients at $6,12,24,48$, and $72 \mathrm{~h}$ after cardiorespiratory arrest. Neurologic outcome was assessed 6 mo after the arrest. Patients with a poor neurologic outcome had significantly higher NSE levels than those with a good neurologic outcome at $12,24,48$, and $72 \mathrm{~h}$. The NSE value at $72 \mathrm{~h}$ was the best predictor of neurologic outcome. In addition to this, it was found that patients with good neurologic outcome had decreasing levels of NSE, whereas patients with adverse neurologic outcome had rising levels of NSE after $6 \mathrm{~h}$, presumably indicating ongoing neuronal damage. The time course of NSE in our animal model correlates well with Schorkhueber's study.

In conclusion, NSE and S100B measured in serum of hypoxic piglets increased significantly after 24 and $48 \mathrm{~h}$, respectively, and correlated with histologic outcome. NSE and S100B may be useful predictors of outcome after hypoxic/ischemic reperfusion injury but cannot be used as predictors within the "window of opportunity" for the initiation of neural rescue therapy. However, they may be useful to establish the timing of an insult.

Acknowledgments. The authors thank Dr. B. Lingwood, Dr. K. Foster, Ms. J. Deviney, and Ms. G. Healy for their help with the experiments; Ms. G. Bellingham and Mr. G. Koerbin for performing the assays; Dr. C.J. Burke for the histological assessment; and Dr. M.W. Davies for assistance with the statistical analysis.

\section{REFERENCES}

1. Thornberg E, Thiringer K, Hagberg H, Kjellmer I 1995 Neuron specific enolase in asphyxiated newborns: association with encephalopathy and cerebral function monitor trace. Arch Dis Child Fetal Neonatal Ed 72:F39-F42
2. Hardemark HG, Ericsson N, Kotwica Z, Rundstrom G, Mendel-Hartvig I, Olsson Y, Pahlman S, Persson L 1989 S-100 protein and neuron-specific enolase in CSF after experimental traumatic or focal ischaemic brain damage. J Neurosurg 71:727-731

3. Nagdyman N, Komen W, Ko HK, Muller C, Obladen M 2001 Early biochemical indicators of hypoxic-ischemic encephalopathy after birth asphyxia. Pediatr Res 49:502-506

4. Blennow M, Savman K, Ilves P, Thoresen M, Rosengren L 2001 Brain-specific proteins in the cerebrospinal fluid of severely asphyxiated newborn infants. Acta Paediatr 90:1171-1175

5. Isobe T, Takahashi K, Okuyama T $1984 \mathrm{~S} 100 \mathrm{a} 0$ (alpha alpha) protein is present in neurons of central and peripheral nervous system. J Neurochem 43:1494-1496

6. Schmechel D, Marangos PJ, Brightman M 1978 Neuron-specific enolase is a molecular marker for peripheral and central neuroendocrine cells. Nature 276:834-836

7. Persson L, Hardemark HG, Gustafsson J, Rundstrom G, Mendel-Hartvig I, Esscher T, Pahlman S 1987 S-100 protein and neuron-specific enolase in cerebrospinal fluid and serum: markers of cell damage in human central nervous system. Stroke 18:911-918

8. Garcia-Alix A, Cabanas F, Pellicer A, Hernanz A, Stiris TA, Quero J 1994 Neuronspecific enolase and myelin basic protein: relationship of cerebrospinal fluid concentrations to the neurologic condition of asphyxiated full-term infants. Pediatrics 93:234-240

9. Verdu Perez A, Falero MP, Arroyos A, Estevez F, Felix V, Lopez Y, Pantoja A, Ureta A 2001 Blood neuronal specific enolase in newborns with perinatal asphyxia. Rey Neurol 32:714-717

10. Thoresen M, Haaland K, Loberg EM, Whitelaw A, Apricena F, Hanko E, Steen PA 1996 A piglet survival model of posthypoxic encephalopathy. Pediatr Res 40:738748

11. Foster KA, Colditz PB, Lingwood BE, Burke C, Dunster KR, Roberts MS 2001 An improved survival model of hypoxia/ischaemia in the piglet suitable for neuroprotection studies. Brain Res 919:122-131

12. Haaland K, Løberg EM, Steen PA, Thoresen M 1997 Posthypoxic hypothermia in newborn piglets. Pediatr Res 41:505-512

13. Sakimura K, Kushiya E, Obinata M, Odani S, Takahashi Y 1985 Molecular cloning and the nucleotide sequence of cDNA for neuron-specific enolase messenger RNA of rat brain. Proc Natl Acad Sci U S A 82:7453-7457

14. Jiang H, Shah S, Hilt DC 1993 Organization, sequence, and expression of the murine S100 beta gene. Transcriptional regulation by cell type-specific cis-acting regulatory elements. J Biol Chem 268:20502-20511

15. Kuwano R, Usui H, Maeda T, Araki K, Kurihara T, Yamakuni T, Ohtsuka E, Ikehara M, Takahashi Y 1986 Molecular cloning and nucleotide sequence of cDNA and genomic DNA for alpha and beta subunits of S100 protein. Taniguchi Symp Brain Sci 9:243-255

16. Mokuno K, Kato K, Kawai K, Matsuoka Y, Yanagi T, Sobue I 1983 Neuron-specific enolase and S-100 protein levels in cerebrospinal fluid of patients with various neurological diseases. J Neurol Sci 60:443-451

17. Missler U, Wiesmann M, Friedrich C, Kaps M 1997 S-100 protein and neuronspecific enolase concentrations in blood as indicators of infarction volume and prognosis in acute ischemic stroke. Stroke 28:1956-1960

18. Schoerkhuber W, Kittler H, Sterz F, Behringer W, Holzer M, Frossard M, Spitzauer S, Laggner ANL 1999 Time course of serum neuron-specific enolase. A predictor of neurological outcome in patients resuscitated from cardiac arrest. Stroke 30:15981603

19. Rosen H, Rosengren L, Herlitz J, Blomstrand C 1998 Increased serum levels of the S-100 protein are associated with hypoxic brain damage after cardiac arrest. Stroke 29:473-477

20. Jonsson H, Johnsson P, Alling C, Westaby S, Blomquist S 1998 Significance of serum S100 release after coronary artery bypass grafting. Ann Thorac Surg 65:1639-1644

21. Elimian A, Figueroa R, Verma U, Visintainer P, Sehgal PB, Tejani N 1998 Amniotic fluid neuron-specific enolase: a role in predicting neonatal neuronal injury? Obstet Gynecol 92:546-550

22. Distefano G, Curreri R, Betta P, Isaja MT, Romeo MG, Amato M 2002 Serial protein S-100 serum levels in preterm babies with perinatal asphyxia and periventricular white matter lesions. Am J Perinatol 19:317-322

23. Lindberg L, Olsson AK, Anderson K, Jogi P 1998 Serum S-100 protein levels after pediatric cardiac operations: a possible new marker for postperfusion cerebral injury. J Thorac Cardiovasc Surg 116:281-285

24. Gazzolo D, Grutzfeld D, Michetti F, Toesca A, Lituania M, Bruschettini M, Dobrzanska A, Bruschettini P 2004 Increased S100B in cerebrospinal fluid of infants with bacterial meningitis: Relationship to brain damage and routine cerebrospinal fluid findings. Clin Chem 50:941-944

25. Volpe J 2000 Neuronal proliferation, migration, organization, and myelination. In Volpe J (ed) Neurology of the Newborn. WB Saunders, Philadelphia, pp 45-99

26. Lipton P 1999 Ischemic cell death in brain neurons. Physiol Rev 79:1431-1568

27. Portera-Cailliau C, Price DL, Martin LJ 1997 Non-NMDA and NMDA receptormediated excitotoxic neuronal deaths in adult brain are morphologically distinct: further evidence for an apoptosis-necrosis continuum. J Comp Neurol 378:88-104

28. Nakajima W, Ishida A, Lange MS, Gabrielson KL, Wilson MA, Martin LJ, Blue ME, Johnston MV 2000 Apoptosis has a prolonged role in the neurodegeneration after hypoxic ischaemia in the newborn rat. J Neurosci 20:7994-8004 